\title{
Application of Cognitive Principles in Distributed Computer-Based Training
}

\author{
Richard C. Deatz and Charlotte H. Campbell \\ Human Resources Research Organization
}

\author{
Armored Forces Research Unit \\ Barbara A. Black, Chief
}

U.S. Army Research Institute for the Behavioral and Social Sciences 5001 Eisenhower Avenue, Alexandria, Virginia 22333-5600

July 2001 